\title{
Lessons to be learned: Reviving advocacy organisations after the neo-con men
}

\author{
Sarah Maddison
}

\begin{abstract}
The article assesses the impact of the Howard years on non-government advocacy organisations in Australia. It stresses the importance of advocacy in civil society, and in representative democracy. It outlines how this role was undermined, including with regard to the manipulation of contracting-out arrangements. It argues that to regain their former role advocacy organisations will need to reassess their relationships with government_-including their funding relationships_-and reassert their role as independent analysts and legitimate critics of government power and policy.
\end{abstract}

\section{Introduction}

If a week is a long time in politics then eleven and a half years is an eternity. For Australian advocacy organisations the eternity of the Howard era will have lasting and detrimental consequences. To regain their former voice and political status advocacy organisations will need to reassess their relationships with government-including their funding relationships_-and reassert their role as independent analysts and legitimate critics of government power and policy.

A change of government alone will not achieve this aim. Over the term of the Howard government non-government advocacy organisations_-like many other institutions of Australian democracy — were systematically eroded by a form of authoritarianism that depicted extra-parliamentary representatives as illegitimate participants in the democratic policy process (see Hamilton \& Maddison 2007). This marginalising of non-government voices had both structural and cultural impacts upon organisational capacity that will take time and effort to overcome. What lessons from the Howard era will help in this project of revitalisation? 


\section{The role of organisations in democracy}

Progressive social movements have long used organisations to structure and mobilise dissent. Movements often grow through organisational membership. Organisations provide connections and contacts, create capacity for coalition, and facilitate communication among members (Minkoff 1997; della Porta \& Diani 1999, p.163; Staggenborg 1998). Organisations are often also seen as the most useful vehicle by which movements can engage with the state. A close relationship with government is often seen as a strategic goal for many movement organisations and it is true that in many ways a close engagement with the state can bring rewards: a seat at the policy table; project and organisational funding; and an increase in public profile and organisational status. By contrast, organisations that remain detached in their relationships with government are often seen as 'outsiders', and may find themselves with little in the way or funding or direct influence (Maddison \& Edgar 2008, p.188).

Advocacy organisations are important in the production of good public policy that is based on knowledge of real people’s lives and experiences. Sometimes this knowledge will come to government attention via public criticism of government policy and programs, and such criticism itself has an important role to play in the democratic policy process as it acts to stimulate public discussion and debate through the dissemination of alternate points of view. Governments can only know of problems or inadequacies in the development and implementation of their policies and programs if they are prepared to listen to critical advice and commentary. Where governments are prepared to listen, criticism and advice from those organisations closest to the problem can help governments provide the best services and develop the best policies for all members of a society. Organisations provide 'democratic legitimacy' when they are involved in public policy processes that see citizens as central to solving community problems’ (Rawsthorne 2004, p.4) and they enhance public accountability and participation through opening up state administration to a 
democratically conceived ‘citizen-based community’ (Yeatman 1998, p. 3). Clearly then, organisations are — or at least should be — recognised as important and beneficial to government.

Perhaps perversely, however, I find myself increasingly of the view that close relationships with government are of greatest benefit to government and may be decidedly detrimental for organisations and movements. In contrast to the view that democratic governments need social movement organisations I would argue that, over time, a close relationship with government may pose a threat to organisational relevance and even survival. This threat is manifest in four key ways. Organisations with a close engagement with government risk a loss of legitimacy, a loss of independence, a loss of organisational resources, and a loss of vision. An historical view suggests that organisations should be cautious in negotiating relationships with government (see Maddison \& Edgar 2008, pp.188-9). The hostility directed towards the non-government organisation sector during the term of the Howard government illustrates this argument clearly.

\section{The damage done}

Over the past decade many have pointed out the extent to which social movement organisations have become marginalised as 'special interest groups' that allegedly make illegitimate claims upon the Australian 'mainstream' (Sawer 2002, Maddison et al 2004, Maddison \& Denniss 2005 inter alia). This rhetoric reflects the Howard Government's acceptance of public choice theory as a guide for working with the public (see Staples 2006). It has also been an effective mechanism for ensuring that criticism of the government is not heard. Marian Sawer has outlined the various mechanisms by which organisations have been marginalised, constrained and silenced, including; 
i. the change from operational funding for representational roles, to project funding attached to outcomes supporting government aims;

ii. the requirement for approved organisational models, specifically, a corporate structure;

iii. an increased reliance on competitive tendering;

iv. Government pressure for groups to amalgamate;

v. pressure to reduce government criticism through disciplinary measures, such as the exclusion of dissident organisations from major advisory boards, and through de-funding said dissidents;

vi. contracts requiring forewarning of media comment by NGOs;

vii. funding agreements including confidentiality clauses, and viii. the Inquiry into the Definition of Charities and Related Organisation, which considered stripping charities with strong advocacy roles of their charity status (Sawer 2002, p. 42-43).

The unprecedented attack upon advocacy organisations during the Howard years, most particularly upon those organisations that represented issues, groups or points of view towards which the government was hostile, represented a distinct departure from previous modes of government-NGO engagement. The attacks came both from key figures within government itself and from close allies such as the Institute of Public Affairs (IPA). Questions were raised publicly about the capacity of advocacy organisations to be representative of their members and accountable for their funding and donation income. Further challenges were issued with regard to their charitable status and to their standing as policy advocates. The IPA decried advocacy organisations as 'selfish and self-serving' interest groups with little representative 
legitimacy. Advocates, service providers and activists within these organisations were seen as groups of professional stirrers who were not really interested in the welfare of those they claimed to represent, but as wanting only to feather their own nests, keeping their salaries and building their power bases (D’Cruz \& Johns 2004, Fox 2006).

The view advocated by the IPA and the Howard government was one largely informed by public choice theory (see Staples 2006). In the public choice paradigm, actions such as policy advocacy, participation and consultation are seen as deceptive strategies designed to disguise the self-interested motives of the 'well-organised minorities’ (Sawer \& Jupp 1996, p.84) who dominate Australian advocacy organisations, and whose true motivation is really what is known disparagingly as 'rent-seeking', or the seeking of additional funding and greater power and influence for their members (Orchard 1998, p.114). These views were echoed publicly by the prime minister himself who spoke of a 'frustrated mainstream' in Australia that resented any perception that government decision-making might be influenced by a the 'powerful vested interests' that apparently dominated advocacy organisations (Howard 1995). Howard later made the claim that he would not allow 'the politically articulate' to 'dominate at the expense of the unorganised mainstream of Australian society’ (Howard 2006). Indeed, far from allowing advocacy organisations to 'dominate' public debate the Howard years saw such organisations pushed further and further to the margins of legitimate public participation. The accompanying changes in funding and taxation regimes further influenced many organisations to retreat to their roles as service providers rather than risk the loss of necessary income or charitable status. As a result many also lost capacity and expertise with regard to lobbying and advocacy. 


\section{The challenges of service provision}

Organisations involved in service provision have faced specific challenges to their advocacy role. Since colonial times, Australia has relied heavily on the voluntary or non-government sector for the provision of social welfare services. Over time, governments have provided varying degrees of funding and other support to enable this work, encouraging a wide range of community-based initiatives and drawing an array of non-government into the government fold while still allowing them considerable independence and autonomy in relation to their programs and operations (Industry Commission 1995; Brennan 1998). Over time, the role of the nongovernment sector evolved from a focus purely on charitable welfare provision to a more professionalised network of service provision organisations that considered policy advocacy to be an important part of their role. In the 1970s public sector reforms saw an increased emphasis on the importance of communication between government and community, particularly though enhanced consultation with nongovernment organisations (Brennan 1998, p.125).

Since the 1990s, however, neo-liberal reforms have emphasised the need for 'smaller', more efficient government. As a result many services that traditionally had been provided by government were increasingly contracted out to the community sector. For some organisations, taking on the role of service provider has meant substantial additional funding, often accompanied by a closer connection to government. In the process, however, these organisations have risked losing their legitimacy among other advocacy organisations in their field; they have risked losing their independence from government when seduced by high levels of funding; they have risked losing resources as governments exploit divisions between insiders and outsiders, and ultimately they have risked losing their vision and sense of purpose. In these circumstances organisations become tamed or captured (Maddison \& Edgar 2008, pp.207-8). 
For many organisations this situation has left them between a rock and a hard place. While some recognise the constraints on advocacy that come with government funding — the view that they should not 'bite the hand that feeds them — they are simultaneously frustrated by their lack of voice. Organisations fear losing the funding with which they provide essential services to marginalised groups. They fear the fate of their clients were this funding to disappear, recognising that in a restricted welfare state they have become the only remaining safety net for vulnerable groups and individuals. For many such organisations, the decision has been to stay silent about structural inequalities and ineffective policies and programs rather than risk their funding and thus their ability to provide a service. For these organisations, particularly small organisations, the choice of rejecting government funding has often seemed like no choice at all.

Over the period of the Howard government a clear division emerged between favoured organisations, which were well-funded and gained representation on various influential public bodies, and those on the outer because they were seen as critical of government. It was evident that the philosophies of favoured organisations tended to be closely aligned with the philosophies of the government. Over time, however, even these favoured organisations began to find their relationships with government increasingly challenging. In 2006 several faith-based service-provider organisations including Catholic Welfare Australia, the St Vincent de Paul Society and the Uniting Church, which had previously been close to the Howard government, with whom they shared a conservative worldview, elected to pull out of their contracts to deliver the government's controversial welfare-to-work reforms. The new regime of governmentfunded ‘service provision’ would see sole parents and those on disability pensions stripped of benefits for eight weeks should they fail to comply with onerous work 
tests. The organisations pulling out of their contracts with government described the reforms as 'dangerous' and 'humiliating'. Several charities refused to take up, or later withdrew, from contracts to provide the financial case management services required under the new provisions for fear of compromising their relationships with vulnerable clients (ABC 2006, Catholic News 2006).

However, large, multi-site organisations such as these, which also enjoy the backing of a large church, are in a different situation to small, single-site and community based organisations. Small organisations are often dependent on government contracts and project funding for their very survival. These organisations-often closest to the 'coal face' in terms of being able to document and report on the impact of government services-may well have been forced to close were they to pull out of their government funding contracts. In such cases organisations were effectively silenced, forced to retreat to a more timid and marginal position in which they were unable to speak up about the injustices they observed.

\section{The need for independence}

How, then, should non-government advocacy organisations imagine and plan for their futures after the neo-con men? One lesson concerns the need to take a long-term view of working closely with government. Exploiting opportunities and becoming close to government, including through a dependency on government funding, may be effective in the short term, and along the way there may be benefits in terms of certain policy outcomes. In the longer term, however, those organisations that are close to, or dependent upon, government risk losing their skills as effective critics of government policies and programs. Without an effective and critical voice, organisations risk further marginalisation. 
A more cautious perspective on future relationships with government is particularly important in the context of a new government that is promising a revitalisation of the relationship between government and the non-government sector. In its first year in office the Rudd government has announced the removal of the so-called 'gag clauses' that during the Howard era were frequently included in government contracts with government-funded organisations. The removal of the gag clauses allows organisations to once again make public comment without first clearing their statements with the relevant minister or department. In announcing the removal of the gag clauses Rudd’s Deputy Prime Minister, Julia Gillard, acknowledged that nongovernment organisations had been living in what she called a 'climate of fear' during the Howard years. Gillard went on to argue that the Rudd government did not want to 'stifle debate' arguing that the new government wanted to:

... ensure that this country ends up with the best possible policy. This requires us to get the gag off and listen to those who know what's going on... We want to make sure that [non-government organisations] can have their say and still be treated fairly by governments ... You only get the best possible public policy if you have the debate. The former government took the view that silence was better. We take the view that debate and hearing everybody's voices is much better (quoted in Franklin \& Lunn 2008).

This rhetoric is certainly promising, and one proposed tonic for reviving the relationship between government and the non-government sector is the 'national compact' that has been suggested by the Rudd government. Compacts are nonbinding agreements between governments and non-government organisations that provide a framework for allowing both parties to work together productively and for 'mutual benefit' (Casey et al 2008, p.3). The Rudd government has specifically proposed such an agreement as a means of renewing their relationship with the nongovernment advocacy sector in Australia, a suggestion that has been welcomed by many. 
However recent work by Gemma Edgar (2008) suggests that advocacy organisations should approach such a proposal with great caution, primarily because compacts themselves are unable to guarantee the enduring legitimacy of non-government advocacy. Considering both international and Australian evidence Edgar concludes that compacts cannot be relied upon to ensure an effective and respectful long-term relationship between government and NGOs and suggests that advocacy organisations should instead direct their energies towards achieving greater public recognition for their important independent role as advocates in public policy debates (Edgar 2008, p.41).

Such advice is timely. There can be little doubt that the Rudd government will seek a stronger and more engaged relationship with the non-government sector than did their predecessors; indeed it could hardly be otherwise. However the trials of the Howard government should serve as an ongoing reminder that governments come and go, and that what matters in the long run is the capacity of non-government advocacy organisations to survive and thrive in bad times as well as good.

\section{References}

Australian Broadcasting Corporation 2006, 'Major charities believe new welfare rules are unfair', The World Today, ABC Radio, 30 June, <http://www.abc.net.au/worldtoday/content/2006/s1675802.htm>.

Brennan, D. 1998, 'Government and Civil Society: Restructuring Community Services', in B. Cass \& P. Smyth (eds), Contesting the Australian Way: States, Markets and Civil Society, Cambridge University Press, Melbourne, pp. 124137.

Casey, J., Dalton, B., Onyx, J. and Melville, R. 2008, 'Advocacy in the Age of Compacts: Regulating government-community sector relations: International experiences', Centre for Australian Community Organisations and Management, Working Paper Series No. 76, February. 
Catholic News 2006, 'New welfare-to-work rules spell disaster: Catholic Social Services', 3 July, <http://www.cathnews.com/news/ 607/3.php>.

D’Cruz, D. \& Johns, G. 2004, 'Green charities and partisan political campaigning', IPA Review, vol. 56, no. 2.

della Porta, D. \& Diani, M. 1999, Social Movements: An introduction, Basil Blackwell, Oxford.

Edgar, G. 2008, Agreeing to Disagree: Maintaining dissent in the NGO sector, Discussion Paper No. 100, The Australia Institute, Canberra.

Fox, R. 2006, 'Promoting freedom and community: civil society organisations in Australia', IPA Backgrounder, vol.18, no.2.

Franklin, M. \& Lunn, S. 2008, 'Critics in 'climate of fear': Gillard', The Australian, 9 January. <www.theaustralian.news.com.au/story/ 0,25197,23025956601,00.html >

Hamilton, C. \& Maddison, S. (2007), (eds), Silencing dissent: How the Australian government is controlling public opinion and stifling debate, Allen and Unwin, Sydney.

Howard, J. 2006, 'Taxation: Keeping faith with Australian families', Transcript of the Prime Minister the Hon John Howard MP, Address to the Menzies Research Centre, Great Hall, Parliament House, 18 April 2006.

Howard, J. 1995, 'The Role of Government: A modern liberal approach', The Menzies Research Centre 1995 National Lecture Series, 6 June.

Industry Commission 1995, 'Charitable Organisations in Australia', Report 45, Australian Government Publishing Service, Melbourne.

Maddison, S., Denniss, R. \& Hamilton, C. 2004, Silencing Dissent: Non- government organisations and Australian democracy, Discussion Paper No. 65, The Australia Institute, Canberra.

Maddison, S. \& Denniss, R. (2005), 'Democratic constraint and embrace: Implications for progressive non-government advocacy organizations in Australia', Australian Journal of Political Science, vol. 40, no. 3, pp. 373-390.

Maddison, S. \& Edgar, G. 2008, 'Into the lion's den: Challenges for NFPs in their relationships with government', in Barraket, J. (ed) Strategic issues in the not for profit sector, UNSW Press, Sydney.

Minkoff, D. 1997, 'Producing social capital: National social movements and civil society’, American Behavioural Scientist, vol. 40, no. 5, pp. 606-619.

Orchard, L. 1998, 'Public sector reform and the Australian way', in B. Cass \& P. Smyth (eds) Contesting the Australian Way: States, Markets and Civil Society, Cambridge University Press, Melbourne.

Rawsthorne, M. 2004, 'Government/Non-government partnerships: Towards deliberative democracy in policy making?' A discussion paper for the Western Sydney Community Forum, Inc.

Sawer, M. 2002, 'Governing for the Mainstream: Implications for Community Representation', Australian Journal of Public Administration, vol. 61, no. 1, pp. 39-49. 
Sawer, M. \& Jupp, J. 1998, 'The two-way street: government shaping of communitybased advocacy', Australian Journal of Public Administration, vol. 5, no. 54, pp. 82-99.

Staggenborg, S. 1998, 'Social Movement Communities and Cycles of Protest: The emergence and maintenance of a local women's movement', Social Problems, vol. 45, no. 2, pp. 180-204.

Staples, J. 2006, 'NGOs out in the cold: the Howard Government policy towards NGOs’, Discussion Paper 19/06, June 2006, Democratic Audit of Australia, Canberra.

Yeatman, A. 1998, Activism and the Policy Process, Allen \& Unwin, Sydney. 